\title{
marketing.
}

Članci/Papers

\section{Determinants of Household Consumption in Serbia - Methodological Approaches and Empirical Results}

\author{
Hasan Hanić, Milica Bugarčić
}

\begin{abstract}
Apstract: The subject of this paper is to quantify the impact of income (household income) which is a key economic variable that determines the framework for personal consumption of households. In addition to income, the influence of household regional affiliation, household size, socio-economic status of the household, gender, age and level of education of the household head - variables that independently affect consumption, increasing or decreasing the influence of income as the main explanatory variables, was examined. The aim of this paper is to provide insight into different methodological approaches to empirical / econometric research of determinants of consumer demand, on the example of empirical analysis of family budgets of households in Serbia. Based on the survey on the consumption of 6,354 households in Serbia, which was conducted in 2019, according to the unique methodology of the European Agency for Statistics, by the Statistical Office of the Republic of Serbia, the basic parameters of consumer demand were assessed. Two econometric approaches were applied: a model based on complete systems of regression equations and a model based on one regression equation. The obtained empirical results are in accordance with the findings of most econometricians of applied consumer demand analysis.
\end{abstract}

Keywords: consumption, income, demand elasticity, complete system regression equation, single equation regression.

\section{JEL Classification: M31}

Napomena: Rad je u formi prethodnog saopštenja predstavljen na naučnoj konferenciji „Izazovi i perspektive marketinga“ održanoj na Zlatiboru od 5. do 7. novembra 2021. godine i prihvaćen je za publikovanje u zborniku radova čiji je izdavač časopis Marketing.

\section{INTRODUCTION}

The volume, structure and dynamics of personal consumption of households are determined by numerous factors, such as the following: preferences and incomes of households, prices of certain products and services, size and composition of households, age and educational structure, occupation of household head, regional affiliation and other demographic and socioeconomic characteristics. The aim of this paper is to provide insight into different methodological approaches to empirical/ econometric research determinants of consumer demand and to quantify the impact of income and other determinants of household consumption, such as regional affiliation, household size, socioeconomic status, gender, age and level of education of the household head, etc.

Two approaches were used in estimating the parameters of the personal consumption system: the complex (systemic) approach and the partial approach. The first approach is based on the premise that household demand for products and services is formed simultaneously, and that all products and services are connected into a comprehensive consumption system through the structure of needs. The complex approach, which is in line with the requirements of consumer demand theory, implies that the parameters of demand and consumption are estimated simultaneously on the basis of complete systems of regression equations. This approach implies that expenditures for individual products and services can be broken down into quantity and price components in order to assess direct and cross price elasticities of demand. Using this approach, using the econometric model „Almost Perfect Demand System“ (AIDS), the income and price elasticities of demand for products belonging to the group Food and non-alcoholic beverages, which is considered as a relatively comprehensive and autonomous consumption system, were estimated. 
The second, partial approach to estimating consumer demand parameters was applied in consumption modeling for all product groups and subgroups contained in the Unified Classification of Products for Personal Consumption of Households adopted by the European Statistics Agency (EUROSTAT). After conducting diagnostic tests, functional forms of Engel curves were selected that best describe the process of forming household demand for individual products, or groups of products and services, and then using appropriate methods to assess key demand parameters.

The importance and relevance of the topic which is the subject of research is confirmed by a large number of econometric studies and scientific papers that have been continuously published in high-ranking scientific journals for more than a hundred years. In addition to the significance of the results for economic policy makers, the obtained results are of special importance for producers and providers of analyzed products and services both for forecasting sales and marketing policy, which should be based on information on patterns of behavior of the households as the carriers of the demand in the market for products and services used for personal consumption.

\section{METHODOLOGICAL APPROACHES TO CONSUMER DEMAND RESEARCH}

Two approaches are used to investigate the impact of income and prices on the demand (consumption or expenditure) of individuals or households:

a complex approach that implies econometric modeling of demand using complete systems of regression equations of demand

$$
\begin{aligned}
& q_{1}=f_{1}\left(m, p_{1}, p_{2}, \ldots, p_{n}\right)+\varepsilon_{1} \\
& q_{2}=f_{2}\left(m, p_{1}, p_{2}, \ldots, p_{n}\right)+\varepsilon_{2} \\
& \vdots \\
& q_{n}=f_{n}\left(m, p_{1}, p_{2}, \ldots, p_{n}\right)+\varepsilon_{n} .
\end{aligned}
$$

and a partial approach that implies econometric modeling using a regression demand equation.

$q=f\left(m, p_{1}, p_{2}, \ldots, p_{n}\right)+\varepsilon$

where individual symbols have the following meanings:

$m, q_{i}$ and $p_{i}$ respectively indicate the consumer's income, demand for the $i$-th product (service) and the price of the observed product $f_{i}(i=1,2, \ldots, n)$ denotes the mathematical form, i.e. the selected econometric specification of the model

$f_{i}\left(m, p_{1}, p_{2}, \ldots, p_{n}\right)$ denotes the systematic component of demand for the $i$-th product, which according to the chosen mathematical form generates variations in consumer income and prices of individual products

$\varepsilon_{i}(i=1,2, \ldots, n)$ means the stochastic component generated by the random mechanism of demand formation, including all other factors that randomly, independently of each other, affect the structure of personal consumption of consumers, while their individual impact on demand for individual products is relatively small.

\subsection{A complex approach to demand analysis}

Empirical, i.e. econometric modelling of demand using the model of complete systems of regression equations has its complete theoretical foundation. This approach to modelling implies that the demand for a particular product or service is viewed as an element of the overall demand system.

Starting from the requirements set by the theory of consumer demand, which primarily relate to the homogeneity and additivity of the demand system, various functional forms of econometric models of complete systems of regression equations have been developed, which are listed below.

\section{Working-Leser (WL) model}

$w_{i}=a_{i}+b_{i} \log X+\sum_{j=1}^{N} c_{i j} \log p_{j} \quad i=1,2, \ldots, n$

where $m$ represents the total disposable income, $p_{j}$ the price of the $j$-th product, $w_{i}$ the share of expenditures for the $i$-th product in the total consumer income, $\alpha_{i}$ i $\beta_{i}$ model parameters, and $\varepsilon_{i}$ error term.

This model was first applied in the mid-1930s, when Working (1943) conducted a study of the impact of income on household consumption in the United States on a sample of about 16,000 households, classifying household expenditures into five broadly defined groups: 1) food, 2) furniture, 3) clothing, 4) recreation and transport and 5) other expenses.

Due to its simplicity, the WL model of complete systems of systems of demand equations has been used in numerous empirical studies. Researchers who have applied this model in the last two decades include: Beneito (2003), Yeong-Sheng et al. (2008), Mohamed, Abdullah and Radam (2009), Dudek (2011), Al-Habashneh and Al-Majali (2014). 


\section{Linear Expenditure System (LES)}

$$
p_{i} q_{i}=p_{i} \gamma_{i}+\beta_{i}\left(m-\sum_{j=1}^{n} p_{j} \gamma_{j}\right), i=1,2, \ldots, n
$$

Where parameters $\beta_{i}$ and $\gamma_{i}$ meet the conditions

$$
0<\beta_{i}<1, \sum_{i=1}^{n} \beta_{i}=1,0 \leq \gamma_{i}<q_{i}
$$

The LES model was formulated by the famous econometrician R. Stone (1954), who applied this model to the analysis of consumption in the United Kingdom, based on annual data from time series from 1920 to 1938, breaking down total consumption into six broadly defined product groups and services: 1) meat and dairy products, 2) fruits and vegetables, 3) beverages and tobacco, 4) current household expenditures (rent, heating, lighting, etc.), 5) durable consumer goods, and 6) other consumer goods and services.

Later, other econometricians used the LES model and some of its modified specifications such as: Pollak and Wales (1969), Sasaki and Fukagawa (1987), Luo and Song (2012) and others.

\section{Additive-logarithmic model (ADILOG)}

$$
w_{i}=\frac{A_{i} \alpha_{i}\left(\frac{p_{i}}{m}\right)^{\alpha_{i}-1}}{\sum_{k=1}^{n} A_{k} \alpha_{k}\left(\frac{p_{k}}{m}\right)^{\alpha_{k}}}(i=1,2, \ldots, n)
$$

Where parameters $A_{i}$ and $\alpha_{i}$ meet the condition $A_{i} \alpha_{i}>0(i=1,2, \ldots, n)$.

\section{Transcendent logarithmic model (TRANSLOG)}

$$
\frac{p_{j} q_{j}}{m}=\frac{\alpha_{j}+\sum \beta_{j i} \ln q_{i}}{\alpha_{m}+\sum \beta_{m i} \ln q_{i}}(j=1,2, \ldots, n) .
$$

In this model of complete systems of demand equations, as in the ADILOG model, budget participations appear as dependent variables. The translog model of complete systems of equations was developed by Christensen, Jorgenson, and Lau (1975), and they applied it to the analysis of personal consumption in the United States for the period 1929-1972.

\section{Rotterdam model with absolute prices (RM-AP)}

$$
\begin{aligned}
& w_{i} d\left(\log q_{i}\right)= \\
& =\mu_{i}\left[d(\log m)-\sum_{j=1}^{n} w_{j} d\left(\log p_{j}\right)+\sum_{k=1}^{n} \pi_{i k} d\left(\log p_{k}\right)\right] \\
& (i=1,2, \ldots, n)
\end{aligned}
$$

where $\mu_{i}$ and $\pi_{i k}$ respectively represent the income and price parameters of the model, developed by Rotterdam econometrician $\mathrm{H}$. Theil. He applied this model in the analysis of demand in the Netherlands based on data from time series of market statistics in the periods 1922-1939 and 1949-1963.

\section{Rotterdam model with relative prices (RM-RP)}

$w_{i} d\left(\log q_{i}\right)=\mu_{i}\left[d(\log m)-\sum_{j=1}^{n} w_{j}\left(\log p_{j}\right)\right]$
$+\sum_{k=1}^{n} v_{i k}\left[d\left(\log p_{k}\right)-\sum_{j=1}^{n} \mu_{j} d\left(\log p_{j}\right)\right] \quad(i=1,2, \ldots, n)$

where $v_{i k}$ represents a specific price parameter of the model, formulated by Rotterdam econometrician A. P. Barten.

\section{Almost Ideal Demand System (AIDS)}

$w_{i}=\alpha_{i}+\sum_{j} \gamma_{i j} \log p_{j}+\beta_{i} \log \{q / P\} \quad(i=1,2, \ldots, n)$

where $P$ stands for the price index defined as follows $\log P=\alpha_{0}+\sum_{k} \alpha_{k} \log p_{k}+\frac{1}{2} \sum_{k} \sum_{j} \gamma_{k j} \log p_{k} \log p_{j}$

The AIDS model, formulated by Deaton and Muellbauer in 1980, shows budget shares that are linearly related to the logarithmic values of explanatory variables related to real consumer income and the prices of individual products and services on which disposable income is spent.

The AIDS model and its linear approximation (LA / AIDS) have been used by a large number of econometricians in empirical studies of personal consumption, i.e. household consumption: Pollak and Wales (1981), Blanciforti and Green (1983), Barten (1993), Abdulai (2002), Mittal (2006), Sahinli and Ozcelik (2015), Ojoko and Umbugadu (2016), Henningsen (2017), Ahn, Lee and Lee (2020), and others. 


\section{Quadratic Almost Ideal Demand System (QUAIDS)}

$$
\begin{aligned}
& w_{i}=\alpha_{i}+\sum_{j=1}^{n} \gamma_{i j} \ln p_{j} \\
& +\beta_{i} \ln \left[\frac{m}{a(p)}\right]+\frac{\lambda_{i}}{b(p)}\left\{\ln \left[\frac{m}{a(p)}\right]\right\}^{2}(i=1,2, \ldots, n)
\end{aligned}
$$

represents an improved version of the AIDS model developed by Banks, Blundell, and Lewbel (1997).

In the last two decades, an increasing number of authors have used the QUAIDS model: Abdulai (2002), Xi, Mittelhammer and Heckelei (2004), Mittal (2006), Barnett and Usui (2007), Dybczak et al. (2014), De Agostini (2014), Gostkowski (2018), Hanić and Bugarčić (2019).

\subsection{Partial approach to demand analysis}

The aforementioned functional forms of complete system models meet the requirements set by consumer demand theory. The results of the theory, expressed in the form of relations between model parameters, help to reduce the number of unknown parameters that certain functional forms contain. However, the remaining number of unknown parameters to be evaluated is very large compared to the realistically available number of observations.

Due to methodological problems that occur when estimating the parameters of complete systems of regression equations (relatively large number of unknown parameters in relation to the number of realistically available observations and complicated procedures for estimating parameters) in empirical analysis of demand more often uses partial approach which means that the demand for a certain product or service is observed in isolation from the demand for other products and services that are part of the consumer's personal consumption. Consequently, the parameters of the selected functional form of the regression equation $f$ are estimated independently of other equations of consumer demand, which is why this approach is called partial econometric modeling of demand using the model of a regression equation.

Investigation of the impact of income on household expenditures using the model of one regression equation

$$
q=f\left(m, p_{1}, p_{2}, \ldots, p_{n}\right)+\varepsilon
$$

involves determining the functional form of the regression equation that adequately describes the quan- titative dependence of expenditures on household income and prices of products and services that enter the personal consumption of households and evaluating the parameters of the selected functional form of the model based on observed values of dependent and explanatory variables.

To estimate income and price elasticities of demand, it is necessary to choose a functional form of regression equation that adequately describes the quantitative dependence of expenditures on household income and prices of products and services that enter personal household consumption for a given set of empirical observations.

When evaluating the parameters of the selected functional form of the model of household expenditure on products and services formulated in the form of one regression equation, several methodological questions are raised: first, how many price variables to include in the model; second, how to provide a sufficiently long series of data on the values of all variables included in the model so that the variables show significant variability; third, how to satisfy the condition of multiple linear regression model that there is no statistically significant linear covariance between explanatory variables; and fourth, how to eliminate the influence of other variables that can vary significantly during the analyzed period and that their variations systematically affect expenditures.

Dueto the difficultiesin solvingtheafore-mentioned methodological problems, for quantification of the impact of income on expenditures for certain groups of products use the so-called cross-data and econometric techniques based on them. In this case, the analysis of demand or expenditure for certain groups of products and services is based on the implicit assumption that the prices of all products and services are constant $\left[p_{1}=p_{2}=\ldots=p_{n}=C\right.$, where $C$ is a constant $]$, so that the model (11) can be presented as

$q=h(m)$ that is $q=h(m)+\varepsilon$

which is known in the literature as the Engel demand model (consumption or expenditure), and the corresponding graphical representation of the function $q=h(m)$ called the Engel curve.

In empirical research on the dependence of demand on household income, econometricians generally use one or several of a dozen known functional forms. Using the codes $Y$ and $X$ for household expenditure and income, below are six econometric specifications of Engel's model (and derived income elasticities $E$ ) 
that we used, which are most commonly used in empirical analysis of consumer demand:

Linear model: $Y=\alpha+\beta X+\varepsilon, \quad E=\frac{\beta}{Y}$

Square model: $Y=\alpha+\beta \log X+\gamma X^{2}+\varepsilon$,

$$
E=\frac{X}{Y}(\beta-2 \gamma X)
$$

Log-log model: $\log Y=\alpha+\beta \log X+\varepsilon, \quad E=\beta(15)$

Lin-log model: $Y=\alpha+\beta \log X+\varepsilon, \quad E=\frac{\beta}{Y}$

Reciprocal model: $Y=\alpha+\frac{\beta}{X}+\varepsilon, E=\frac{\beta}{\alpha X-\beta}$

Log-reciprocal model: $\log Y=\alpha-\frac{\beta}{X}+\varepsilon, E=\frac{\beta}{X}$

\section{DATA, SAMPLE STRUCTURE AND EMPIRICAL RESULTS}

Given the structure of the household budget questionnaire, data collected by the Household Budget Survey in Serbia allow examining the impact of a number of socio-economic and demographic household variables, such as household size, regional household affiliation, education level of household head, gender of household head and dr. which are assumed to be able to affect household expenditures in addition to income or in interaction with income.

In order to isolate variations in consumption due to heterogeneity of households in terms of household size and regional affiliation, level of education and gender of household head and other relevant characteristics, a stratification of the sample of households surveyed in 2019 was performed. In terms of size, households are divided into three strata: 1) singlemember households, 2) households with two, three or four members, and 3) households with more than four members; according to the region to which the household belongs, four strata were formed: 1) Belgrade, 2) Vojvodina, 3) Sumadija and Western Serbia, 4) Southern and Eastern Serbia; according to the socio-economic status of households, three strata are distinguished: 1) households with a monthly income of up to 50,000 dinars, 2) households with a monthly income of 50,000 to 90,000 dinars, and 3) households with a monthly income of over 90,000 dinars; according to the level of education of the household head, households are divided into three strata: 1) completed primary school, 2) completed secondary school, and 3) completed at least higher school; according to the age of the household head, the sample units are classified into three statues: 1) up to 40 years of age, 2) from 40 to 60 years, and 3) over 60 years; while two strata were formed on the basis of the sex of the head of the household.

To solve the problem of heterogeneity of regression parameters, instead of using artificial (dummy) variables, as well as estimating regressions for each sample stratum, we used the Simmingly Unrelated Regression (SUR) model.

To assess the impact of household size on the amount of household expenditure, the SUR1 model was set up in the form of a system of three regression equations, corresponding to the sample strata, and whose parameters are simultaneously assessed:

1) Single member households

$Y_{-} 1_{i}=\alpha+\beta X_{-} 1_{i}+\varepsilon_{-} 1_{i}$

2) From two to four household members

$Y \_24_{i}=\alpha+\beta X_{-} 24_{i}+\varepsilon_{-} 24_{i}$

3) More than four household members

$Y_{-} 5_{i}=\alpha+\beta X_{-} 5_{i}+\varepsilon_{-} 5_{i}$

Similarly, to examine the impact of income on household expenditure depending on the region to which the household belongs, a SUR2 model with four regression equations was formulated:

1) Belgrade

$$
Y \_b g_{i}=\alpha+\beta X_{-} b g_{i}+\varepsilon_{-} b g_{i}
$$

2) Vojvodina

$$
Y_{-} v o j_{i}=\alpha+\beta X_{-} v o j_{i}+\varepsilon_{-} v o j_{i}
$$

3) Sumadija and Western Serbia

$$
Y_{-} \text {šum } m_{i}=\alpha+\beta X_{-} \check{\text { šum }}{ }_{i}+\varepsilon_{-} \check{\text { šum }} \text { i }
$$

4) South and Eastern Serbia

$$
Y_{-} j u g_{i}=\alpha+\beta X_{-} j u g_{i}+\varepsilon_{-} j u g_{i}
$$

Similarly, to examine the impact of socio-economic status on the dependence of expenditure on household income, the SUR3 model was formulated, consisting of three regression equations whose parameters are estimated simultaneously:

1) Average monthly household income up to 50,000 dinars

$$
Y_{-} 50_{i}=\alpha+\beta X_{-} 50_{i}+\varepsilon_{-} 50_{i}
$$

2) Average monthly household income from 50,000 to 90,000 dinars

$$
Y_{-} 59_{i}=\alpha+\beta X_{-} 59_{i}+\varepsilon_{-} 59_{i}
$$


3) Average monthly household income over 90,000 dinars

$$
Y_{-} 90_{i}=\alpha+\beta X \_90_{i}+\varepsilon_{-} 90_{i}
$$

In order to examine the impact of household income on expenditures for individual groups of products and services depending on the level of education of the household head, the SUR4 model was formulated:

1) Completed elementary school

$$
Y_{-} o \check{s}_{i}=\alpha+\beta X_{-} o \check{s}_{i}+\varepsilon_{-} o \check{s}_{i}
$$

2) Completed secondary school

$$
Y_{-} s \check{s}_{i}=\alpha+\beta X_{-} s \check{s}_{i}+\varepsilon_{-} s \check{s}_{i}
$$

3) Completed vocational school

$$
Y_{-} v \check{s}_{i}=\alpha+\beta X_{-} v \check{s}_{i}+\varepsilon_{-} v \check{s}_{i}
$$

The influence of the age of the household head on the dependence of household demand for individual groups of products and services on the amount of income was examined using the SUR5 model:

1) Up to 40 years of age

$$
Y_{-} 40_{i}=\alpha+\beta X_{-} 40_{i}+\varepsilon_{-} 40_{i}
$$

2) Between 40 and 60 years of age

$$
Y_{-} 46_{i}=\alpha+\beta X_{-} 46_{i}+\varepsilon_{-} 46_{i}
$$

3) Over 60 years of age

$$
Y_{-} 60_{i}=\alpha+\beta X X_{-} 60_{i}+\varepsilon_{-} 60_{i}
$$

Finally, the SUR6 model, which consists of two regression equations, was used to examine the influence of the household head's gender on the dependence of household consumption on income.

\section{1) Male}

$$
Y_{-} m_{i}=\alpha+\beta X_{-} m_{i}+\varepsilon_{-} m_{i}
$$

2) Female

$$
Y_{-} \check{z}_{i}=\alpha+\beta X_{-} \check{z}_{i}+\varepsilon_{-} \check{z}_{i}
$$

As it has been said, the impact of the income on household expenditures was investigated using the data collected on the basis of the household budget survey, which has been conducted every year since 2003 by the Statistical Office of the Republic of Serbia according to international standards and recommendations of the EU Agency for Statistics (EUROSTAT), International labor organizations and the United $\mathrm{Na}$ tions.

Databases on household consumption contain the characteristics of each surveyed household, including each individual member, and very detailed data on income and personal consumption, which is classified into 12 groups according to the Classification of Products and Services of Personal Consumption by Purpose (COICOP) further subdivided into sub- groups, and subgroups into subgroups that include highly individualized products and services.

Figure 1 provides an insight into the distribution of households according to the stipulated socio-economic and demographic characteristics of households, while Figure 2 shows the structure of total expenditures of Serbian households in 2019.

Empirical results of the analysis of household consumption obtained by applying the partial econometric approach are shown in Table 1 . For all 12 product groups, income elasticities of expenditures are shown, for each used functional form on the basis of which they were calculated. Based on statistical tests to verify the significance of the model, it was shown that for nine of the 12 groups of products and services, the double-logarithmic functional form is the best econometric specification, while the square form was identified as the best in the remaining three groups (Alcoholic beverages and tobacco, Health and Recreation and culture).

Based on the numerical values of income elasticities shown in Table 1, and in accordance with the theory of consumer demand, which postulates that the group of necessary goods includes goods with income elasticity less than one, it turned out that the necessary goods status have products belonging to the following groups: Food and non-alcoholic beverages, Alcoholic beverages and tobacco, Housing, water, electricity, gas and other fuels, House equipment and maintenance and Health. Services and products in the field of Communications, Restaurants and hotels and Other personal items and services belong to the group of products with normal income elasticity (income elasticity is close to one), while Clothing and footwear, Transport, Recreation and culture and Education, where elasticity is significantly higher of one have the status of luxury goods.

Similar results in terms of elasticity were obtained by some other authors: Yusof and Duasa (2010) who are 2007/2008. conducted a survey in Malaysia on a sample of 2,649 households; Al-Habashneh and AlMajali (2014) who conducted a survey in 2010 on a sample of 13,866 urban and rural households in Jordan; Hanić, Bugarčić and Dacić (2020) who conducted a consumption analysis on a sample of 7,702 households in Bosnia and Herzegovina and 6,531 households in Serbia in 2015; Hanić and Bugarčić (2020) who analysed the structure and dynamics of household consumption in Serbia in the period from 2006 to 2019.

In order to examine the impact of the observed socio-economic and demographic characteristics of 


\section{FigURE 1. Distribution of households according to their socio-economic and demographic characteristics}
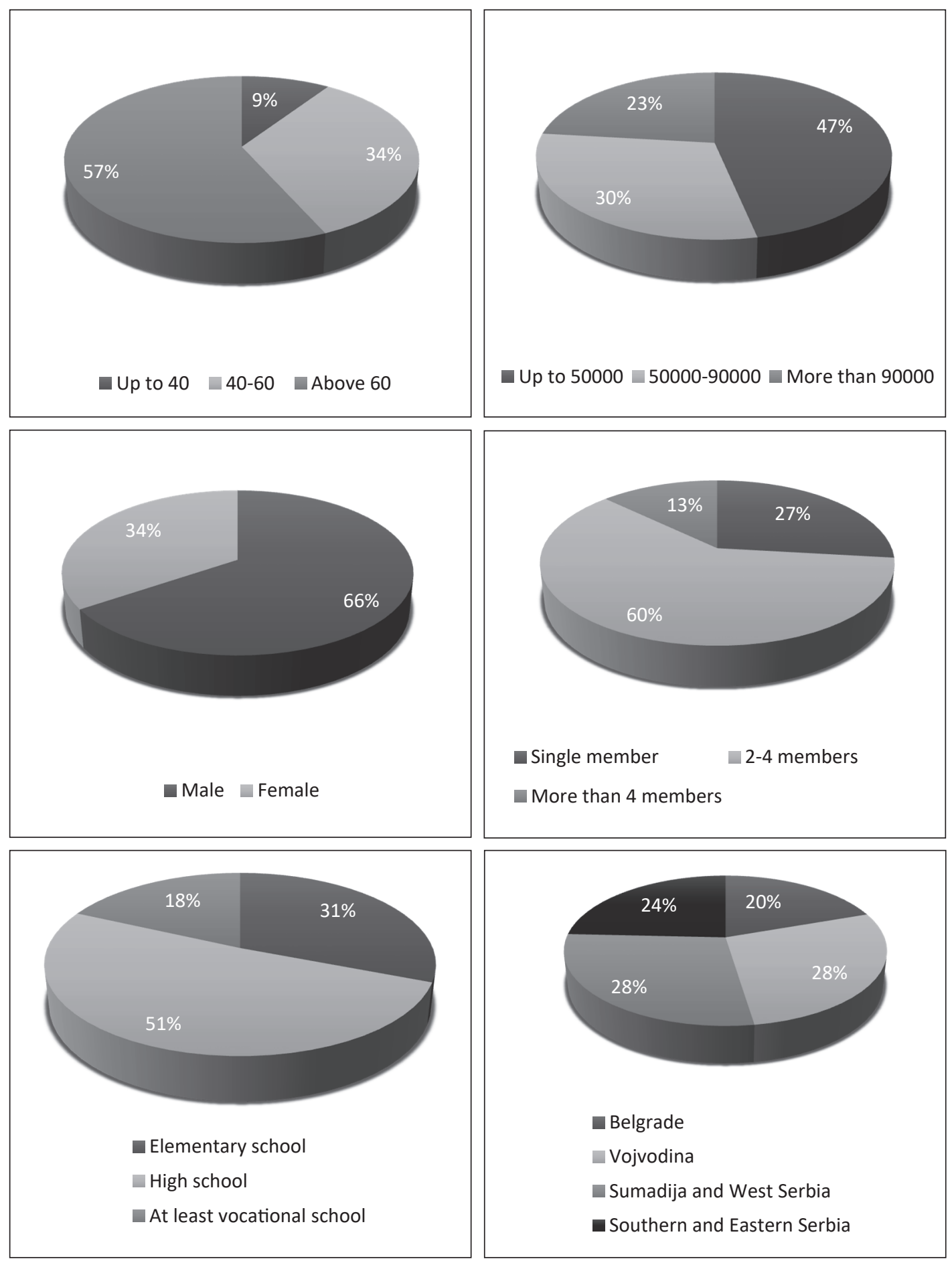

households on expenditures for individual groups of products and services, the parameters of the SUR model were first estimated. Then at the level of significance of $1 \%$ the statistical difference was estimated between the estimated parameters and basic

explanatory variable income. Statistical analysis of the obtained results showed that, with the exception of household size, each individual socio-economic and demographic factor significantly affects the dependence of household consumption on income for 


\section{marketing}

\section{FigURE 2. Structure of Serbian household expenditures in 2019}

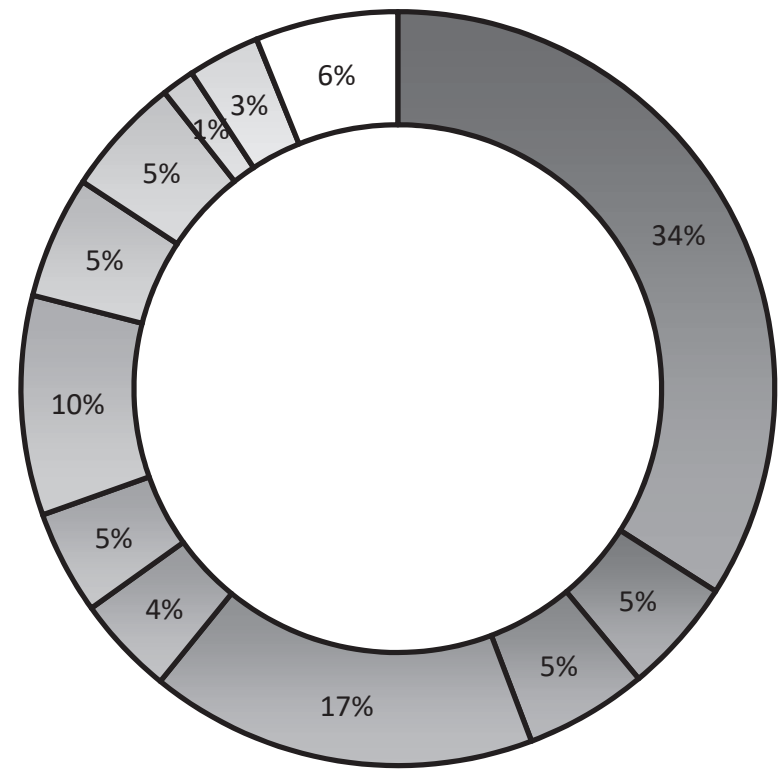

$\square$ Food and non-alcoholic beverages
$\square$ Alcoholic beverages and tobacco
$\square$ Clothing and footwear
$\square$ Housing, water, electricity, gas and other
fuels
$\square$ Furnishings, household equipment and
routine household maintenance
$\square$ Health
$\square$ Transport
$\square$ Communication
$\square$ Recreation and culture
$\square$ Education
$\square$ Restaurants and hotels
$\square$ Miscellaneous goods and services

all groups of products and services. Our findings are consistent with the results of empirical analysis of the impact of socio-economic and demographic factors obtained by numerous researchers, including Yusof and Duasa (2010), Sekhampu and Niyimbanira (2013), Al-Habashneh and Al-Majali (2014), Manajit, Samutachak and Voelker (2020), etc.

Given the geographical variation of product prices, based on data obtained from household surveys, the quantitative and price component of expenditures can be distinguished for certain categories of expenditures using a special technique. This enabled us to apply the AIDS model to quantify the impact of not only income but also prices on expenditures, i.e. the share of expenditures for nine categories of products from the group Food and non-alcoholic beverages, which was assumed to be a relatively independent consumption system. Appendices 3-5 show the numerical values of

TABLE 1. Functional forms and income elasticities

\begin{tabular}{|l|c|c|c|c|c|c|}
\hline Form & Linear & Log-Log & Lin-Log & Square & Inverse & Log-inverse \\
\hline Food and non-alcoholic beverages & 0.78 & $\mathbf{0 . 6 5}$ & 0.73 & 0.41 & 0.34 & 0.36 \\
\hline Alcoholic beverages and tobacco & 1.03 & 0.75 & 1.02 & $\mathbf{0 . 8 1}$ & 0.49 & 0.47 \\
\hline Clothing and footwear & 1.39 & $\mathbf{1 . 3 7}$ & 1.42 & 1.86 & 0.64 & 1.00 \\
\hline $\begin{array}{l}\text { Housing, water, electricity, gas and } \\
\text { other fuels }\end{array}$ & 0.76 & $\mathbf{0 . 7 9}$ & 0.8 & 1.05 & 0.39 & 0.45 \\
\hline $\begin{array}{l}\text { Furnishings, household equipment } \\
\text { and routine household maintenance }\end{array}$ & 1.01 & $\mathbf{0 . 9 0}$ & 0.98 & 1.03 & 0.44 & 0.49 \\
\hline Health & 0.78 & 0.54 & 0.75 & $\mathbf{0 . 6 5}$ & 0.35 & 0.29 \\
\hline Transport & 1.51 & $\mathbf{1 . 5 6}$ & 1.44 & 1.57 & 0.63 & 1.06 \\
\hline Communications & 0.68 & $\mathbf{0 . 9 9}$ & 0.81 & 1.20 & 0.42 & 0.62 \\
\hline Recreation and culture & 1.83 & 1.30 & 1.65 & $\mathbf{1 . 9 1}$ & 0.68 & 0.84 \\
\hline Education & 2.12 & $\mathbf{1 . 1 1}$ & 1.98 & 2.83 & 0.8 & 1.25 \\
\hline Restaurants and hotels & 1.29 & $\mathbf{1 . 0 8}$ & 1.34 & 1.71 & 0.61 & 0.82 \\
\hline Miscellaneous goods and services & 1.05 & $\mathbf{1 . 0 7}$ & 1.05 & 1.19 & 0.48 & 0.59 \\
\hline
\end{tabular}


the direct and cross price elasticities of Cournot, the yield elasticities of Engel, the direct and cross price elasticities of Slutsky, and the direct and cross price elasticities of Hicks-Allen, which were calculated as follows:

$$
\begin{aligned}
e_{i k} & =\frac{p_{k}}{q_{i}} \frac{\partial q_{i}}{\partial p_{k}}(i, k=1,2, \ldots, n)(\text { Cournot }) \\
\eta_{i} & =\frac{m}{q_{i}} \frac{\partial q_{i}}{\partial m}(i=1,2, \ldots, n)(\text { Engel }) \\
e_{i k}^{*} & =\frac{p_{k}}{q_{i}}\left(\frac{\partial q_{i}}{\partial p_{k}}\right)_{U=C}(i, k=1,2, \ldots, n) \text { (Slutsky) } \\
\sigma_{i k} & =\frac{e_{i k}^{*}}{w_{i}}(i, k=1,2, \ldots, n) \text { (Hicks-Allen) }
\end{aligned}
$$

Based on the estimated price and income elasticities, it can be noted that the conditions implied by the theory of consumer demand are met as follows: 1) the sum of the Cournot elasticities is equal to Engel's elasticity of demand for these goods, with the opposite sign; 2) the sum of the values of the Cournot elasticities of demand weighted by the shares of expenditures for a given group of products is equal to one; 3 ) the sum of all Slutsky elasticities that express individual net price influences on the demand for the observed product is equal to zero; and 4) all (except one) Slutsky's direct elasticities are negative.

\section{CONCLUSION}

Based on statistical indicators of the quality of model adjustment to empirical data (coefficient of determination and information criteria), it was determined that of all econometric specifications of regression models, the log-log model, which implies constant income elasticity, best represents the dependence of household expenditures on income and income groups. The results of the empirical analysis of house- hold consumption in Serbia in 2019, based on partial modelling of consumption by the method of one regression equation, show that the status of necessary goods (where consumption is inelastic in relation to income) have products belonging to the groups Food and soft drinks, Alcoholic beverages and tobacco, Housing, water, electricity, gas and other fuels, Housing and maintenance equipment and Health. The status of "normal“ products (in which the elasticity is approximately equal to one) have products from the group Communications, Restaurants and hotels and Other personal items and services, while Clothing and footwear, Transport, Recreation and culture and Education have the status of luxury goods (where income elasticity is greater than one).

Using the SUR model, it was determined that the observed socio-economic and demographic factors affect the dependence of expenditures for all groups of products and services on household income, except in the case of household size which does not statistically significantly affect the dependence of expenditure on education on income.

Based on empirical results obtained by modelling expenditures for subgroups of food and non-alcoholic beverages using the AIDS model, which is a very popular econometric specification of complete systems of regression equations for individual groups, subgroups and individual products, it is shown that direct and cross price elasticities of Cournot, Engel's income elasticities, Slutsky's direct and cross price elasticities, and Hicks-Allen direct and cross price elasticities satisfy the restrictions and limitations of the theoretical model of consumer demand: 1) the sum of Cournot's elasticities is equal to Engel's elasticity of demand; 2) the sum of the values of Cournot's elasticities of demand weighted by the shares of expenditures for a given group of products is equal to one; 3 ) the sum of all Slutsky's elasticities expressing individual net price influences on the demand for the observed product is equal to zero; and 4) all (except one) Slutsky's direct elasticities are negative.

\section{References}

1. Abdulai, A., 2002. Household demand for food in Switzerland. A quadratic almost ideal demand system. Revue Suisse D Economie Et De Statistique, 138(1), pp.1-18.

2. Ahn, Y. J., Lee, B. C., \& Lee, S. K. (2020). Analysis of Korean millennials' travel expenditure patterns: an almost ideal demand system approach. Asia Pacific Journal of Tourism Research, 25(1), 3-14.

3. Al-Habashneh, F. \& Al-Majali, K. (2014). Estimating the Engel Curves for household expenditures in Jordan from 2010 to 2011. European Scientific Journal, ESJ, 10(2). 
4. Banks, J., Blundell, R. and Lewbel, A., 1997. Quadratic Engel curves and consumer demand. Review of Economics and statistics, 79(4), pp.527-539.

5. Barten, A.P. (1993). Consumer allocation models: choice of functional form. Empirical Economics, 18(1), 129-158.

6. Barnett, W.A. and Usui, I., 2007. The theoretical regularity properties of the normalized quadratic consumer demand model. In Functional Structure Inference (pp. 107-127). Emerald Group Publishing Limited.

7. Beneito, P. (2003). A complete system of Engel curves in the Spanish conomy. Applied Economics, 35(7), 803-816.

8. Blanciforti, L. and Green, R., 1983. An almost ideal demand system incorporating habits: an analysis of expenditures on food and aggregate commodity groups. The Review of Economics and Statistics, pp.511-515.

9. Christensen, L.R., Jorgenson, D.W. \& Lau, L.J. (1975). Transcendental logarithmic utility functions. The American Economic Review, 65(3), 367-383.

10. De Agostini, P. (2014). The effect of food prices and household income on the British diet (No. 2014-10). ISER Working Paper Series.

11. Deaton, A. \& Muellbauer, J. (1980). An almost ideal demand system. The American economic review, 70(3), 312-326.

12. Dudek, H., 2013. Equivalence scales for Polandnew evidence using complete demand systems approach. Research Papers of Wrocław University of Economics, (308), pp.128-143.

13. Dybczak, K., Tóth, P. and Voňka, D., 2014. Effects of price shocks on consumer demand: Estimating the QUAIDS demand system on Czech household budget survey data. Czech Journal of Economics and Finance, 64(6), pp.476-500.

14. Gostkowski, M., 2018. Elasticity of Consumer Demand: Estimation Using a Quadratic Almost Ideal Demand System. Econometrics, 22(1), pp.68-78.

15. Hanić, H., \& Bugarčić, M. (2019). Econometric modeling of household consumption of alcoholic beverages and tobacco by complete system of regression equations. In Econometric modeling in economics and finance, Belgrade: Institute of Economic Sciences, 35-37.

16. Hanić, H., Bugarčić, M. 2020. Examination of the Influence of Impact on Tobacco Consumption in Serbia, Economics of Agriculture, Year 67, No. 4, pp. 1217-1232.

17. Hanić, H., Bugarčić, M., Dacić, L. 2020. Examination of the impact of household income on expenditure on clothing and footwear in Bosnia and Herzegovina and Serbia, Sarajevo Business and Economics Review, Vol. 38, pp. 51-78.

18. Henningsen, A. (2017). Demand Analysis with the "Almost Ideal Demand System" in R: Package
micEconAids. Copenhagen: Department of Food and Resource Economics, University of Copenhagen, 1-36.

19. Luo, D. \& Song, B. (2012). Analysis of the income elasticity of the consumer demand of Chinese rural residents and prediction of its trend. Grey Systems: Theory and Application, 2(2), 148-156.

20. Manajit, S., Samutachak, B., \& Voelker, M. (2020). Socio-Economic Determinants of Consumption Patterns in Thailand. Asia-Pacific Social Science Review, 20(2).

21. Mittal, S., 2006. Structural shift in demand for food: projections for 2020 (No. 184). Working paper.

22. Mohamed, Z., Abdullah, A.M. and Radam, A., 2009. Evidence of Engel curves in food away from home: A study of Malaysia. MPRA Paper.

23. Ojoko, E.A. and Umbugadu, G. B., 2016. Factors Influencing Household Expenditure Patterns on Cereal Grains in Nasarawa State, Nigeria. World Academy of Science, Engineering and Technology, International Journal of Social, Behavioral, Educational, Economic, Business and Industrial Engineering, 10(4), pp.1132-1137.

24. Pollak, R. A. \& Wales, T. J. (1969). Estimation of the Linear Expenditure System. Econometrica. Vol. 37, No. 4, 611-628.

25. Pollak, R. A., \& Wales, T. J. (1981). Demographic variables in demand analysis. Econometrica: Journal of the Econometric Society, 1533-1551.

26. Sahinli, M.A. and Ozcelik, A., 2015. An Almost Ideal Demand System: An Application To The Different Commodities For Turkey. Agriculture and Food.

27. Sasaki, K. and Fukagawa, Y. (1987). An analysis of the Japanese expenditure pattern: an application of a dynamic linear expenditure system to the 1961-1982 data. Agribusiness, 3(1), 51-68.

28. Stone, R. (1954). Linear expenditure systems and demand analysis: an application to the pattern of British demand. The Economic Journal, 64(255), 511527.

29. Working, H. (1943). Statistical laws of family expenditure. Journal of the American Statistical Association, 38(221), 43-56.

30. Xi, J., Mittelhammer, R. \& Heckelei, T. (2004). A Quaids Model of Japanese Meat Demand. American Agricultural Economics Association (AAEA). No. 3772016-20756, 76-91.

31. Yeong-Sheng, T.E.Y., Shamsudin, M.N., Mohamed, Z., Abdullah, A.M. \& Radam, A. (2008). Demand analyses of food in Malaysia: Effects of model specification and demographic variables. Germany: University Library of Munich.

32. Yusof, S.A. and Duasa, J., 2010. Consumption patterns and income elasticities in Malaysia. Malaysian Journal of Economic Studies, 47(2), pp.91-106. 


\section{APPENDIX}

APPENDIX 1. Cournot direct and cross-price elasticities and Engel's income elasticities for food and non-alcoholic beverages rated using the AIDS system

\begin{tabular}{|c|c|c|c|c|c|c|c|c|c|c|c|c|}
\hline & HIC & MES & RIB & MSJ & UIM & VIĆ & PVR & KON & PRE & KC̆K & MNS & E \\
\hline HIC & -0.45 & -0.09 & -0.01 & -0.04 & -0.02 & -0.03 & -0.04 & -0.01 & 0.00 & 0.01 & -0.02 & 0.73 \\
\hline MES & -0.11 & -0.40 & -0.07 & -0.12 & -0.03 & -0.06 & -0.10 & -0.04 & -0.05 & -0.08 & -0.04 & 1.11 \\
\hline RIB & -0.31 & -1.11 & 0.37 & -0.33 & -0.05 & -0.09 & -0.27 & -0.12 & -0.15 & -0.29 & -0.07 & 2.31 \\
\hline MSJ & -0.04 & -0.09 & -0.01 & -0.56 & -0.01 & 0.00 & -0.02 & -0.01 & 0.02 & 0.03 & -0.01 & 0.71 \\
\hline UIM & -0.18 & -0.27 & 0.00 & -0.10 & -0.05 & -0.07 & -0.08 & -0.03 & -0.02 & -0.04 & -0.09 & 0.94 \\
\hline VOĆ & -0.12 & -0.21 & 0.01 & -0.03 & -0.03 & -0.16 & -0.10 & 0.00 & -0.01 & 0.00 & -0.03 & 0.69 \\
\hline PVR & -0.07 & -0.14 & -0.02 & -0.04 & -0.01 & -0.04 & -0.26 & -0.04 & -0.03 & 0.00 & -0.04 & 0.70 \\
\hline KON & -0.13 & -0.26 & -0.04 & -0.12 & -0.02 & -0.03 & -0.18 & -0.12 & -0.05 & -0.02 & -0.01 & 1.00 \\
\hline PRE & -0.33 & -1.00 & -0.18 & -0.25 & -0.09 & -0.15 & -0.37 & -0.15 & -0.08 & -0.11 & -0.11 & 2.73 \\
\hline KČK & -0.19 & -0.89 & -0.21 & -0.10 & -0.07 & -0.09 & -0.18 & -0.08 & -0.07 & -0.26 & -0.07 & 2.14 \\
\hline MNS & -0.09 & -0.15 & 0.01 & -0.06 & -0.05 & -0.03 & -0.11 & -0.02 & 0.00 & 0.00 & -0.05 & 0.52 \\
\hline
\end{tabular}

APPENDIX 2. Slutsky's direct and cross price elasticities assessed using the AIDS system

\begin{tabular}{|c|c|c|c|c|c|c|c|c|c|c|c|}
\hline & HIC & MES & RIB & MSJ & UIM & VIǴ & PVR & KON & PRE & KC̆K & MNS \\
\hline HIC & -0.34 & 0.10 & 0.02 & 0.08 & 0.00 & 0.01 & 0.05 & 0.03 & 0.04 & 0.04 & 0.01 \\
\hline MES & 0.05 & -0.11 & -0.02 & 0.06 & 0.01 & 0.01 & 0.04 & 0.02 & 0.01 & -0.03 & 0.01 \\
\hline RIB & 0.04 & -0.50 & 0.47 & 0.05 & 0.03 & 0.06 & 0.02 & 0.00 & -0.02 & -0.18 & 0.03 \\
\hline MSJ & 0.07 & 0.10 & 0.03 & -0.45 & 0.02 & 0.04 & 0.07 & 0.03 & 0.05 & 0.07 & 0.02 \\
\hline UIM & -0.04 & -0.02 & 0.04 & 0.05 & -0.02 & -0.01 & 0.04 & 0.02 & 0.03 & 0.01 & -0.04 \\
\hline VOĆ & -0.02 & -0.03 & 0.04 & 0.08 & -0.01 & -0.12 & -0.02 & 0.03 & 0.03 & 0.03 & 0.00 \\
\hline PVR & 0.04 & 0.04 & 0.02 & 0.07 & 0.01 & 0.00 & -0.17 & 0.00 & 0.01 & 0.03 & -0.01 \\
\hline KON & 0.02 & 0.00 & 0.01 & 0.04 & 0.01 & 0.03 & -0.06 & -0.07 & 0.01 & 0.03 & 0.04 \\
\hline PRE & 0.09 & -0.29 & -0.06 & 0.19 & 0.00 & 0.03 & -0.03 & -0.01 & 0.07 & 0.03 & 0.02 \\
\hline KČK & 0.13 & -0.33 & -0.12 & 0.25 & 0.00 & 0.05 & 0.09 & 0.03 & 0.05 & -0.16 & 0.02 \\
\hline MNS & -0.01 & -0.02 & 0.04 & 0.03 & -0.03 & 0.00 & -0.05 & 0.05 & 0.03 & 0.02 & -0.02 \\
\hline
\end{tabular}

APPENDIX 3. Hicks-Alen direct and cross price elasticities were assessed using the AIDS system

\begin{tabular}{|c|c|c|c|c|c|c|c|c|c|c|c|}
\hline & HIC & MES & RIB & MSJ & UIM & VIć & PVR & KON & PRE & Kc̆K & MNS \\
\hline $\mathrm{HIC}$ & -2.23 & & & & & & & & & & \\
\hline MES & 0.36 & -0.05 & & & & & & & & & \\
\hline $\mathrm{RIB}$ & 0.27 & -0.25 & 10.38 & & & & & & & & \\
\hline MSJ & 0.46 & 0.05 & 0.59 & -2.73 & & & & & & & \\
\hline UIM & -0.27 & -0.01 & 0.91 & 0.32 & -0.60 & & & & & & \\
\hline VOĆ & -0.13 & -0.01 & 0.91 & 0.51 & -0.24 & -1.80 & & & & & \\
\hline PVR & 0.26 & 0.02 & 0.35 & 0.45 & 0.36 & 0.04 & -1.37 & & & & \\
\hline KON & 0.13 & 0.00 & 0.11 & 0.24 & 0.29 & 0.51 & -0.48 & -1.33 & & & \\
\hline PRE & 0.56 & -0.14 & -1.35 & 1.18 & 0.04 & 0.45 & -0.25 & -0.21 & 1.32 & & \\
\hline KČK & 0.88 & -0.16 & -2.56 & 1.52 & 0.07 & 0.69 & 0.69 & 0.60 & 0.90 & -3.31 & \\
\hline MNS & -0.05 & -0.01 & 0.79 & 0.16 & -1.04 & 0.04 & -0.40 & 0.88 & 0.49 & 0.48 & -0.52 \\
\hline $\begin{array}{l}\text { Legend } \\
\text { HIC - Bre } \\
\text { MES - Me } \\
\text { RIB - Fish } \\
\text { MSJ - Mil } \\
\text { UIM - Oils }\end{array}$ & $\begin{array}{l}\text { cheese, } \\
\text { ind fats }\end{array}$ & & & & & $\begin{array}{l}\text { VOĆ - Fru } \\
\text { PVR - Ve } \\
\text { KON - Co } \\
\text { PRE - Fo } \\
\text { KČK - Co } \\
\text { MNS - M }\end{array}$ & $\begin{array}{l}\text { ables } \\
\text { ctionery } \\
\text { broducts } \\
\text { tea, coc } \\
\text { cal water }\end{array}$ & peverag & rruit & veget & \\
\hline
\end{tabular}




\section{marketing}

\section{Apstrakt:}

\section{Determinante potrošnje domaćinstava \\ u Srbiji - metodološki pristupi \\ i empirijski rezultati}

Hasan Hanić, Milica Bugarčić

Predmet ovog rada jeste kvantifikovanje uticaja dohotka (visine primanja domaćinstava) koji predstavlja ključnu ekonomsku varijablu koja određuje okvir za ličnu potrošnju domaćinstava. Pored dohotka, ispitivan je uticaj regionalne pripadnosti domaćinstva, veličine domaćinstva, socijalno-ekonomskog statusa domaćinstva, pola, starosti i nivoa obrazovanja nosioca domaćinstva - varijabli koje samostalno deluju na potrošnju, pojačavajući ili slabeći uticaj dohotka kao glavne eksplanatorne varijable. Cilj rada jeste da pruži uvid u različite metodološke pristupe empirijskim/ekonometrijskim istraživanjima determinanti potrošačke tražnje, na primeru empirijske analize porodičnih budžeta domaćinstava u Srbiji. Na osnovu ankete o potrošnji 6.354 domaćinstava u Srbiji, koju je 2019. godine, prema jedinstvenoj metodologiji Evropske agencije za statistiku, sproveo Zavod za statistiku Republike Srbije, ocenjeni su osnovni parametri potrošačke tražnje. Primenjena su dva ekonometrijska pristupa: model zasnovan na kompletnim sistemima regresionih jednačina i model zasnovan na jednoj regresionoj jednačini. Dobijeni empirijski rezultati su u skladu sa nalazima većine ekonometričara primenjene analize potrošačke tražnje.

Ključne reči: potrošnja, dohodak, elastičnost tražnje, model kompletnih sistema regresionih jednačina, metod jedne regresione jednačine.

\section{Kontakt:}

Hasan Hanić, hasan.hanic@bba.edu.rs Milica Bugarčić, milica.bugarcic@bba.edu.rs Beogradska bankarska akademija - Fakultet za bankarstvo, osiguranje i finansije, Beograd, Srbija 